\title{
Academic Performance Programs: New Directions and (Dis)Connections in Academic Reform
}

\author{
Camille P. O'Bryant \\ California Polytechnic State University
}

\begin{abstract}
The purpose of this paper is to provide a response to Harrison's (2012) work. The author suggests that the one-size-fits all approach the National Collegiate Athletic Association (NCAA) has adopted when implementing academic reform measures ultimately hurts the athletes the reforms are intended to benefit.
\end{abstract}

I would like to begin by thanking the members of the colloquium planning committee for inviting me to serve as a reactor to Harrison's (2012) work. It is an honor to be in the company of so many scholars, administrators and faculty who are committed to keeping the student in the term student-athlete and dedicated to studying the complexities of the structure, organization, and impact of intercollegiate athletics in our nation's colleges and universities. I also want to thank the 100-150 students enrolled in my courses in the psychological and sociological aspects of sport and physical activity each quarter at California Polytechnic State University (Cal Poly) - especially those students who are also athletes. I know how much I enjoyed my intercollegiate sport experiences but also struggled with maintaining an appropriate balance in time between training for my sport and keeping up with my academic responsibilities - and that was in a Division III program, no scholarship, or "pressure to win." I am constantly inspired by the personal, social, and intellectual strength, and determination of the students who participate in intercollegiate sports.

I have organized my remarks as follows: a brief statement of my personal background and professional/academic experiences that provide context for my reaction to the paper and thoughts about academic progress/performance policies, some general reactions to and comments about Dr. Harrison's keynote (2012), suggestions for consideration as members of the Committee on Academic Performance (CAP) and others in the National Collegiate Athletic Association (NCAA) consider new directions for academic reform, and a statement about the need for more institution-specific oversight of academic performance and why the institutional oversight is important.

O'Bryant is with the Kinesiology Department, California Polytechnic State University, San Luis Obispo, CA. 


\section{Personal and Professional Experiences in Athletics and Academics}

I attended Smith College for my undergraduate degree. The first few years of my student-athlete experience were under the auspices of the AIAW (Association for Intercollegiate Athletics for Women). I remember some of the "changes" that occurred for us during my senior year-the first year that my undergraduate college became a NCAA member institution-when we were required to sign multiple documents about our "role" as student-athletes and the academic requirements that would be imposed on us if we wished to continue participating in sport. Although I would have had no trouble meeting the current NCAA core-course requirements in high school, because I attended Girls Latin School in Boston (one of three public schools with an entrance exam requirement, the SAT), as I recall, my score on the SAT would have made it difficult for me to be qualified to participate on a NCAA Division I athletic team, if those rules had been in place in 1978. I tell you these few "historical" facts about myself because they definitely impact my reaction to the academic reform movement in the NCAA in general and the content of Dr. Harrison's paper (2012) in particular.

\section{General Reactions to Harrison}

I commend Dr. Harrison and members of the NCAA Committee on Academic Performance for their thoughtful and critical review of academic performance and reform of policies related to academic performance in NCAA Division I institutions. Guided by the principles of ensuring that student-athletes have real academic opportunities and ensuring that colleges are living up to their academic obligations to student-athletes, CAP's decisions are made with the goal of improving academic success as opposed to punishing students and schools. Basing decisions on the best data available, committing to acquiring data that would support better policies, and continuing to monitor data to track the intended and unintended consequences of CAP's decisions are crucial to on-going academic reform. I also applaud the attempts that Dr. Harrison and members of CAP have made to make theirs a holistic investigation of all NCAA sports-not just football, or women's or men's basketball.

Dr. Harrison and others have described the evolution and future directions for academic reform within the NCAA, but I just wanted to take a moment to remind us all that the NCAA was not the first governing body of intercollegiate sport that came into existence to provide oversight and guidance for the conduct of intercollegiate sport programs. In an overview of the historical timeline of the governance of intercollegiate sport, Acosta and Carpenter (2005) pointed out that Senda Berenson and her contemporaries formed the Women's Basketball Committee (WBC) in 1899. These women physical educators and administrators were concerned with the quality of the athletic experience for women participating in intercollegiate basketball. Basketball grew in popularity very quickly on college campuses, and there were quite a few debates about the competitive nature of the game and role of competition for women in higher education. Unfortunately, there is not time to explore the complexities of the impact of race, gender, and other sociocultural, historical and political factors that influence student success in this 
forum, but I wanted to mention the WBC so that we are all aware of the existence of reform initiatives in intercollegiate sport beyond football and men's basketball.

\section{Impact of Policies on Student Success}

As I read Dr. Harrison's (2012) paper, I kept hearing the following questions come into my mind: what is the impact of these policies; are these academic reform policies really improving student success or are they increasing the gap between athletics and academic programs on our campuses; and how are discussions on student success (i.e., graduation rates) limiting as compared with discussions on student learning? Presenters at this colloquium have spoken very eloquently about the history (Oriard, 2012) of academic reform, the results of academic reform (Paskus, 2012; Petr and McArdle, 2012), and the future of academic reform (Harrison, 2012). Those who have reacted to these presentations have made comments that reinforce the on-going paradoxical nature of intercollegiate sport. Lawrence, Ott, and Hendricks (2009) stated that sport on our college and university campuses have the potential to provide many positive learning experiences off and on the field of play, yet many people involved in intercollegiate sport - the students, coaches, administrators and spectators-often condemn intercollegiate sport for being "excessively commercial, and permitting unethical and even scandalous behavior" (p. 73). The NCAA Academic Performance Program and members of CAP are taking a systematic and empirically based approach to help improve the academic integrity of intercollegiate sport in NCAA Division I programs. But I would suggest that they are just scratching the surface of the need for and impact of athletic academic reform.

As we have heard from speakers at this colloquium (e.g., Fields, 2012) and according to information on the NCAA web page (Academic information about colleges, 2011), NCAA student-athletes have graduated at an increasing rate over the last decade, a period in which they also have consistently graduated at a higher rate than the overall student body. So, are there other factors contributing to this success? Lawry (2005) suggested that we should be cautious when reviewing graduation rates as a good indicator of the "academic health of college athletic teams" (p. 21)

As I browsed the NCAA web page and reviewed the data on academic performance, I asked myself the following question: How does the overall graduation success rate (GSR) compare with the 6-year graduation rate at an actual institution? So, I checked for my institution for the students entering fall 2004. According to data from Cal Poly's Office of Institutional Planning and Analysis (2011), $74.6 \%$ of first-time freshmen entering Cal Poly in fall 2004 graduated within 6 years. From information on the NCAA web page, I found that the overall GSR, as calculated by the NCAA from data that Cal Poly provided to the NCAA, was $72 \%$. However, according to information on the NCAA web page, this percentage is only based on student-athletes who received athletics aid from the college or university for any period of time during their entering year of the GSR calculation (Education \& research, n.d.). I wonder what the GSR would be for all students eligible to participate in intercollegiate athletics at Cal Poly or any other NCAA member institution that is subject to these academic performance policies. Would it be higher or lower? Should we exclude the possible impact or influence of other specific campus policies that influence student success (e.g., policies on expected academic progress or academic probation/disqualification policies)? 
I also wonder about the quality of the students' experience. There is no doubt a great opportunity to link student success with student learning through the process of program review and assessment. Academic programs undergo program review at least once every 5 years and engage in a period of self-study during which faculty members are supposed to reflect on the extent to which students meet the stated program learning objectives. It is through this process of self-study and subsequent peer review that the faculty members are able to explore the quality of the educational programs along with the quantity (e.g., student success as determined by graduation rate) of students we serve in our degree programs. I wonder if such reflection and study of quality of learning experiences for students who participate in athletic programs would be a great way to build more meaningful results from academic reform initiatives.

\section{Suggestions for Consideration}

The comments I am about to make are based on two concerns that came to mind as I read Dr. Harrison's (2012) paper: (a) a need for systematic study of impact of Academic Performance Rate (APR) and GSR in non-BCS (Bowl Championship Series) programs, and (b) the importance of more institution-specific oversight of academic performance of students who participate in intercollegiate sport.

\section{Need for Systematic Study of Impact of APR and GSR in non-BCS programs}

Each person who has presented at this colloquium has alluded to the diversity of and within college and university sport programs. They have all indicated a variety of reasons why a "one-size-fits-all" approach to academic reform is problematic. What I want to spend time talking about is my concern about the potential that these academic reform policies have to widen the gap between college athletics/athletes and the educational values or mission at the colleges and universities-which may be one of the "unintended consequences" that warrants further study.

As I previously noted, many who have addressed this body have discussed concerns about the impact of these reforms on students of color and on institutions with limited fiscal and human resources (e.g., Historically Black Colleges and Universities [HBCU] and primarily Hispanic-serving institutions; see, for example, Cunningham, 2012). I want to ask that we focus more on building bridges and facilitating better communication and connections between athletics and academics.

I am thinking right now about academic/athletic advisors who, according to Meyer (2005), are "inextricably involved in this controversy [surrounding academic reform] . . . and have....perhaps, one of the most challenging jobs in higher education" (p. 15). I concur with Meyer's contention that those who are at the forefront of the reform policies do have the intention of transforming the "culture" of intercollegiate athletics in a manner that ensures "student-athletes are indeed students"; yet, they are not those who "work daily with students" (p. 18). The academic advisors in athletic departments and in academic departments are the ones who are trying to help bridge the gap between NCAA academic reform policies and students in these programs. I have many concerns about the misinformation that students receive from those athletic academic advisors who are unable to or fail to take the time to learn a specific curriculum. In addition, what, if anything, 
does the NCAA leadership know about how coaches and administrators feel about these academic reform policies?

In a preliminary study of APR, Christy, Seifried and Pastore (2008) examined the opinions of athletic directors, faculty athletic representatives, senior women administrators, and head coaches. While this was a preliminary investigation of the impact of APR in intercollegiate athletics, these authors found that $64 \%$ of the respondents felt that APR would have a positive impact on college athletics, namely improving graduation rates of student-athletes and making head coaches more accountable for the type of student-athletes being recruited. Yet, there were still nearly 1 in $3(32 \%)$ of respondents who were very critical of APR as a whole. From Christy et al.'s (2008) discussion, it appeared to me that the main critics of APR were the head coaches of nonrevenue sports. For example, while APR has the potential to ensure or push head coaches to recruit students who are better "prepared" to be successful and complete their college degree, the added pressure on coaches to ensure academic success could result in a "watered down" curriculum (p. 8) or the push for students to take "easier courses" or choose "easier" majors to ensure APR success (p. 8). The respondents in this study raised some critical questions about APR and GSR, and the authors made very important recommendations for future research: examine the attitudes of Division I non-BCS administrators and head coaches to gain a better understanding of how these reforms are negatively impacting students, coaches and administrators at HBCUs and midmajor universities; examine the extent to which APR may widen the gap between the academic success and support between the high end and low end of Division I; and engage in more in-depth, quantitative analysis into the perceptions of the APR.

Presenters have already expressed concern about the clustering of athletes into majors that may make it "easier" for them to meet the standards of academic performance polices rather than choose major fields of study that are more closely aligned with their intellectual and professional interests. Choice of major is a very complex process, and many students change their major, at least once. For example, at our institution, we find that nearly $30 \%$ of the students consider a change of major, with close to $25 \%$ actually changing their major. Fountain and Finley (2011) shared results of their longitudinal analysis of academic clustering in a NCAA Division I football program. They stated that their data supported the occurrence of clustering with the majority of students (53.2\%) selecting or migrating to a major in Apparel, Housing and Resource Management — a phenomenon that was particularly noteworthy for the minority players in their sample. The second most commonly listed major was Sociology, with $13.8 \%$ in that major. Again, we cannot say for certain based on current data if the APR or GSR are the cause for academic clustering, but the trend toward clustering in the wake of academic reform is something that has been visible in a variety of reports related to academic reform in the past two decades.

\section{More Institutional Oversight of Academic Performance}

While I understand that many of the academic reform movements have occurred because of the concern for student success and corruption in high-profile sports in highly visible college sport programs, I would like to suggest that increased efforts from the NCAA to govern or legislate academic progress has led to greater disconnects between athletic departments and the rest of the campus community, ultimately hurting many students. I have been a member of my university's athletic 
advisory board for two years. This board is comprised of students, faculty, athletics representatives, administrators from student affairs, the faculty athletics representative, community members, and the provost. The advisory board serves as an oversight committee for athletics and recommends policy and direction for such issues as the addition or elimination of sports, academic standards, gender equality, and financial integrity. It was during one of the meetings of this board last quarter that we discussed our campus concerns related to the unintended consequences of APR and GSR. For example, the Progress toward Degree (PTD) standards conflicts with our campus academic policies related to academic probation and expected academic progress. Having multiple sets of academic policies and standards (i.e., campus-specific policies and NCAA policies) creates confusion among students, faculty and administrators. It is difficult enough to advise students about their academic rights, responsibilities, curriculum, and career options. Adding another layer of complexity that is inconsistent with local policies (I feel) just increases the perception that student athletes are not really students.

Also, although athletics in our institution falls under the purview of academic programs, the director of athletics has very little voice or visibility with any other administrators on campus other than the president. I think that the director of athletics should be a member of the dean's council and an ex officio member of the academic senate, just like the provost and vice president for student affairs are. The academic policies and resolutions that the faculty and administrators discuss have a direct impact on athletes, yet there is no representation of the athletics director in these forums. Likewise, very few faculty and campus administrators are aware of the complexities of the NCAA Academic Performance Program or mandated requirements related to academic support/advising on our campus. Mandating and legislating more "uniform" or "standardized" academic performance requirements from the NCAA combined with little opportunity for colleges and universities to "tailor" their academic performance expectations to campus-specific mission and resources is making it increasingly difficult for colleges and universities to situate themselves within the educational mission of their campuses, resulting in yet another disconnect between the intent of academic reform initiatives and the lived experiences of the primary stakeholder in intercollegiate athletics-the student.

At this point, there are five general areas of disconnect I suggest university administrators, NCAA staff members, and faculty need to consider as they strive to facilitate student success.

- (Academic) Eligibility/Education: Solely quantitative measures of academic success yield inadequate information about the quality of education or student learning. I hope that there will come a time when there are qualitative measures of student success, which potentially provide more depth and detail about the experiences that student-athletes have had in their athletic programs.

- Student/Athlete: The more the NCAA imposes a one-size-fits-all standard for academic performance, the more individual campuses are trying to reach these standards to avoid penalties. This creates many differences between the educational experiences of students who are participants in intercollegiate sports programs and those who are not.

- Faculty/Administrator: The faculty has the responsibility of developing and implementing curricula that are meaningful and relevant to the wide variety 
of disciplines and participate in a system of shared governance that provides oversight to the students' academic rights and responsibilities. The administrator (the athletic director) has increasingly less voice and visibility in the implementation of campus academic policies yet has to provide leadership for the implementation of "external" (NCAA) policies that are often inconsistent with campus policies.

- Member Institution/NCAA: The diversity of academic performance initiatives and resources to support student success and learning on individual campuses is lost in the wake of a standardized measure of academic performance-even one that is so carefully designed as the recently modified APR and GSR proposed by CAP.

\section{Final Comment and Question for Consideration}

The more the NCAA attempts to create a one-size-fits-all approach to academic reform, the more disconnected intercollegiate athletics becomes from the core campus community. Who ends up falling into this widening abyss?

\section{References}

Academic information about colleges. (2011, May 24). Retrieved from http://www.ncaa. $\mathrm{org} / \mathrm{wps} / \mathrm{wcm} / \mathrm{connect} /$ public/NCAA/Academics/How+academic+reform+is+measured

Acosta, V., \& Carpenter, L. (2005). Title IX. Champaign, IL: Human Kinetics.

Cal Poly Office of Institutional Planning \& Analysis (2011, September 26). Retrieved from www.ipa.calpoly.edu

Christy, K., Seifried, C., \& Pastore, D. (2008). Intercollegiate athletics: A preliminary study examining the opinions on the impact of academic performance rate (APR). Journal of Issues in Intercollegiate Athletics, 1, 1-10.

Cunningham, G.B. (2012). Diversity issues in academic reform. Journal of Intercollegiate Sport, 5, 54-59.

Education \& research: GSR search. (n.d.). Retrieved from http://fs.ncaa.org/Docs/newmedia/ public/rates/index.html

Fields, S.K. (2012). Are we asking the right questions? A response to the academic reforms research by Todd Petr and Tom Paskus. Journal of Intercollegiate Sport, 5, 60-64.

Fountain, J.J., \& Finley, P.S. (2011). Academic clustering: A longitudinal analysis of a Division I football program. Journal of Issues in Intercollegiate Athletics, 4, $24-41$.

Harrison, W. (2012). NCAA academic performance program: Future directions. Journal of Intercollegiate Sport, 5, 65-82.

Lawrence, J., Ott, M., \& Hendricks, L. (2009). Athletics reform and faculty perceptions. New Directions for Higher Education, 148, 73-81 10.1002/he. doi:10.1002/he.370

Lawry, A.C. (2005). Academic integrity and college athletics. Phi Kappa Phi Forum, 85(3), $20-23$.

Meyer, S.K. (2005). NCAA academic reforms: Maintaining the balance between academics and athletics. Phi Kappa Phi Forum, 85(3), 15-18.

Oriard, M. (2012). NCAA academic reform: History, context and challenges. Journal of Intercollegiate Sport, 5, 4-18.

Paskus, T. (2012). A summary and commentary on the quantitative results of current NCAA academic reforms. Journal of Intercollegiate Sport, 5, 41-53.

Petr, T., \& McArdle, J.J. (2012). Academic research and reform: A history of the empirical basis for NCAA academic policy. Journal of Intercollegiate Sport, 5, $27-41$. 